\title{
Students' Perception and Preferences on Teachers' Written Feedback in ESL Writing
}

\author{
Thiviyaa Maniam, Parilah Mohd Shah
}

\begin{abstract}
Feedback is one of the prominent aspects in teaching and learning a language. In the context of second language writing, it serves a significant role in acquiring the language effectively. Although the expectations and needs of feedback for each student may differ, they are often not given an opportunity to select the type of feedback of their choice. Hence, this study aims to identify students' perception and preferences on teachers' written feedback in enhancing their writing skill. For that, a survey research design with a quantitative approach was employed whereby the data was gained from a set of Likert scale questionnaires adapted from Seker \& Dincer (2014). A total of 94 students from a Chinese Independent High School in Klang Valley were the respondents of this study. The results were analyzed through descriptive statistics by calculating frequencies and percentages. The study revealed that students perceive teacher's written feedbacks as a crucial element in the development of their writing skill and it has an emotional impact in their language learning. Therefore, teachers are suggested to pay more attention to students' perception and preferences on written feedback that can further guide in optimum language learning among students.
\end{abstract}

Index Terms - Teacher's Written Feedback, ESL writing, Students' Perception, Students' Preference.

\section{INTRODUCTION}

Writing is also measured as the most difficult skills to master by ESL learners compared to listening, reading and speaking because it includes problem solving and organizing approaches that helps attain communicative objectives [22] [32]. This has always been the case in students with all levels ranging from primary to tertiary. However, one of the most challenging stage in enhancing writing skill is during secondary education. This is supported by Nooreiny \& Mazlin [39] who mentioned writing of senior high school students including native speakers, second and foreign language learners, are considered as an important challenge. Therefore, special care has to be taken in order to ensure appropriate methods of instruction is employed in the instruction of writing skill in English language which is the L2 of our country.

One of the effective ways to provide feedback is through written feedback. According to Zhan [51], teachers' written feedback plays is a major influence in developing students' writing skills. It is also considered that written feedbacks are possibly considered as important by students compared to ones provided to clusters of learners [24]. Based on Cohen \&

Thiviyaa Maniam, National University of Malaysia, 43600, Bangi, Selangor, Malaysia

Parilah Mohd Shah, (Associate Professor Dr.) National University of Malaysia, 43600, Bangi, Selangor, Malaysia.
Cavalcanti [14], written response is a central element of the writing process. Numerous researches studying the consequence of written response on learners' writing have revealed that the process of a feedback in the written form aids learners expand the writing skills [12][20][29][30].

In the Malaysian context, Ministry of Education Malaysia, 1986 provided some guiding principle for teachers on ways to instruct writing. It highlights that the writing course must focus on teaching composition that must be taught step-by-step. This stipulates a need for the process approach which is highlighted in the English curriculum of secondary schools [37]. The extensive use of process approach in teaching writing requires a strong support of feedback system. Therefore, teachers' written feedback would be an apt choice of feedback system to reinforce students' writing skill. Chinese Independent schools on the other hand do not adhere to the same education system as in National schools due to the difference in medium of instruction [49]. Unlike National school students, these students compulsorily sit for UEC (Unified Examination Certificate) examinations which is the public exam designed for Chinese Independent School students. UEC examination is constructed based on the educational syllabus of Taiwan. Although English is a must-pass subject to obtain the certificate, Chinese Independent school students are said to have a low proficiency in English language as they give priority to Mandarin compared to English and thus have lesser exposure to the language [13]. As UEC examinations focuses only on reading and writing skills, it is highly significant to provide appropriate instructions to mold these skills to obtain good results in the examination. The selected school opts to employ process approach in teaching and learning of essay compositions as it possesses various benefits for teachers and students [31].

This study will help novice researchers concentrating on students' insights of the written feedback process in writing of second language learners. The study is conducted in anticipation that both instructors and learners become aware of the types of teachers' written feedback that are preferred by students and the types which will help them improvise their writing skill. Generally, educators would approve the inevitability of giving feedback in students writing tasks. However, despite being given written feedbacks, it is noticeable that students tend to repeat mistakes [3]. Students often make minor alterations on their grammar and sentence structure errors based on teachers' remarks but rarely revise their ideas and contents of the composition. This may be due to lack of motivation or emotional connected to the type of feedback provided to the by their teachers. Hence, it is utmost 
important to determine the perception and preference of students so that they show involvement in the feedback and make profound effort in correcting themselves.

Most researches on the students' perception of teacher written feedback has been conducted on tertiary level students' and very few has been explored in Malaysian secondary school context [43] and even fewer were conducted in the context of Malaysian Chinese Independent High School. Thus, it is hoped that the outcome from this study will be able to help ESL teachers and students to further progress in the teaching and learning of ESL writing. This research may fill a gap by signifying the views, expectation and most preferred written feedback of a Chinese Independent High School students in improving the quality of writing in essays.

As mentioned by Hyland \& Hyland [28], any verdict made in the process of getting and providing feedback should centralize learning as its focus and a great importance should be given in obtaining students' perception in doing so. Therefore, this study aims to determine Chinese Independent High School students' perception on teachers' written feedback and to identify students' preference on teacher's written feedback in essays. With regards to the objective, this study aims to respond to the question: 'What are the students' perceptions on teacher's written feedback?' and 'What are the students' preference on teacher's written feedback?'

\section{LITERATURE REVIEW}

\section{A. Written Feedback in ESL Writing}

Nicol and Macfarlane [38] stressed that feedback as an educator's scope and describe it as teachers' knowledge that aid students identify their accomplishment. Carless [11] highlighted the social aspects of the term, and explains feedback as a social process that involves discourse, control, feelings, and process influence. In brief, feedback basically means useful knowledge given to a novice that enables improvement in their performance. Williams [50] described that the aim of feedback in L2 writing is to impart the skills that benefit students improve their writing proficiency until they are aware of what is expected and are capable to provide it with least errors and more clarity. Written feedback refers to feedbacks given in the form of comments and correction in students written task. It is defined as a method used to notify a student about the accuracy of their response [33]. This type of feedback is time consuming as teachers have to think about what and how to write the feedback. One of the profound feedbacks in students' writing involves written corrective feedback (WCF). WCF refers to the classroom practice in which students receive corrections on their writing products [45]. There are four main types of WCF, namely, direct feedback whereby teacher does the error correction on students' writing, indirect feedback whereby teacher points out the error made but does not correct the error, focused feedback where a certain type of error is corrected (i.e past simple) and unfocused where teachers corrects all the errors made in writing [16]. This study focuses on direct, indirect and unfocused WCF. The effectiveness of WCF has been a debate throughout the years and has produced various responses from researchers. Corrective feedback is regarded as ineffective and harmful due to the pressure it possesses on students to write accurately [46][47]. This is forcefully objected by Ferris [19] who then claims that the opinion against WCF is premature and overly strong. This is supported by Bitchener \& Knoch, [9] who claims that students perceive WCF as helpful and effective to improve their writing and emphasized the need of focused corrective feedback for effective learning. Studies on end and marginal comments have proven to be helpful in improving students' writing performance [18]. Fithriani [21] asserts that written feedback comprises of global matters such as ideas, content and organization of the writing and local matters such as grammar accuracy, spelling, punctuation, and formatting of the writing. She also asserts that the commentary is presented either in the form of commendation, disapproval, or recommendation. The mixed perceptions received on the usefulness of WCF has generated the need for further research in this field.

\section{B. Students'Perception and Preference on Written Feedback.}

Studies on learners' insights on various feedback constructs commenced in 1990s [35]. As a result of those researches, it was found that learners' response differs significantly on teacher feedback and they desire diverse kinds of feedback for various motives [51]. Perception means comprehension of a person and state of consciousness of the surrounding via processing feeling in the cognitive field. This process involves the mental development (logical thinking and reasoning) and emotional development (feelings, emotions, attitudes, values, and motivations) [44]. Emotion is one of the important areas to discuss when exploring students' perceptions of feedback in ESL writing classrooms. Higgins et al [25] explained that feedback in L2 writing classrooms is significantly connected to power and emotion. With regards to power, the teacher has the roles of supporting and delivering opinion on the student. Barnard et al., [8] discovered that emotions are inseparably connected to the perceptions of students of the advantages of feedback in writing classrooms. In conclusion, emotions undeniably impact the manner in which students gain and process feedback. There are certain factors that contribute to the perception or preference of students. Rather than assuming students' understanding on teachers' feedback, teachers should consider the context in which the feedback is provided to better cater to their needs. Some of the context are linguistic, educational, socio-economic and cultural background of the students [23][4][7].

Students' preferences on teachers' written feedback vary in terms of the area of language. Students' preferences are mainly separated as form focused which covers local issues and content focused which covers global issues. Many studies have shown students' preference on form-oriented (local) feedback such as grammar accuracy or vocabulary [36][5][34]. On the other hand, several studies have also showed that students prefer content based (global) feedback such as organization or meaning [1][6][21]. Despite the differences in the preferences, the need for a combination of both types of written feedback is prevalent in this domain of study [17][18]. 


\section{Studies Related to Written Feedback}

Many researches have been conducted to identify students' perception and view on teachers' written feedback on students. Most of them involves tertiary level students as respondents. One of them are conducted by Ameli et 1. [3] on students' opinion and choices of written feedback in writing. The study concluded that students opt for comments that are detailed and precise. Thus, teachers are suggested to demonstrate honest attention in students' work and respond elaborately via explicit points or specifics of the writing. Precise comments created positive influence in the students' writing. Fithriani [21] conducted a research on the perceptions of written feedback by university students in L2 writing in the context of Indonesia. The results of the study described that benefitted from written feedback. Students mentioned that their writing skill was upgraded after integrating teacher's and peers' written feedback. Saidon et al., [41] carried out a research on ESL students' view on teacher's written feedback. The study implied that the participants of the study who are Malaysian Secondary School students thought that the written feedback from teacher assisted them in improving their writing. Zhan [51] conducted a study on teachers and student's viewpoint of teachers' written feedback. The outcome of the study concluded that students found certain type of written feedback as useful in improving their writing skill. $\mathrm{He}$ suggested that teachers should be aware of students' perceptions about their feedback practices in class. Seker \& Dincer [42] conducted a research to gain insight on students' opinion on teachers' feedback in ESL classes. From the study, EFL students from a University in Turkey revealed that feedback on all constructs of writing as helpful for language improvement. It also revealed that there was relationship between students' emotions and their action initiation time.

\section{Methodology}

\section{A. Research Design}

This study employed a survey research design with a quantitative approach to examine the perception of students on written feedback. Bryman [10] stated that quantitative research approach is a research that sets importance on digits and figures in the compilation and examination of data. Hence, the study emphasizes on the descriptive statistic using frequency and percentage calculation.

\section{B. Population and Sample}

The samples of this study were chosen based on random sampling. 94 respondents were randomly selected from a Chinese Independent High School located in Klang Valley from a population of 403 students. They consist of 16-year-old Senior One students who belong to intermediate, upper-intermediate and advanced level of language proficiency. They comprise of 34 male students and 60 female students. They were chosen because they have 3 years of exposure to teacher's written feedback which is sufficient to provide appropriate response for this study.

\section{Instrument}

The questionnaire adapted from Seker \& Dincer [42] were used as an instrument of this study. The items used in this survey are closed-ended questionnaires which were converted to an online survey in Google Forms because it was not possible to meet students face to face as the school was shut down due to Movement Control Order (MCO). The questionnaire consists of two sections. The first section encompassed queries on demographic information, such as gender, age and language competence level. The next section consists 23 items that determines students' feelings upon receiving written feedback and their preferences on the area of language in teacher's written feedback. The items on students' feelings consist of positive feelings such as improved, cared for, satisfied, etc. and negative feelings such as humiliated, unsatisfied, disappointed, etc. There are also items to identify their feelings when they have to wait long for teachers' written feedback. Next, students' preferences are determined through items which specify the language area that they prefer such as vocabulary, content, grammar, etc. The questionnaire was presented in a 4-point Likert scale. The questionnaires are anchored by scales consisting strongly disagree (1), disagree (2), agree (3) and strongly agree (4). The reliability of the scale was measured via Cronbach's Alpha Coefficient [15]. The outcome of the reliability test denoted that the scale had high internal reliability $(\alpha=0.859)$ and was fit to carry out further statistical tests.

\section{Data Collection Procedure}

The students have already been practicing process approach since they were in Junior 1 . This means they have 3 years of exposure to teachers' written feedback. As usual, they made two drafts before submitting the final outcome. Students were given a duration of one week to complete the first draft of essay composition. Then, on the second week, after they had submitted the first draft of the essay, teachers played their designated roles which is to mark the essay and provide written feedback. The same process was repeated for a second draft before finalizing the end product of the essay writing task. Then, teachers sent an online survey consisting a questionnaire with 23 items through Google Forms in order to perceive students' perception and preference on teacher's written feedback. Due to the pandemic, students were taught using Google Meet and their essays were submitted and marked through Google Classroom. The instructions and guidance on how to complete the survey were given through their respective Google Meet sessions.

\section{E. Data Analysis}

The data for the research was analyzed through Statistical Package for the Social Science (SPSS Ver.21). The research questions of this study are measured with descriptive statistics to identify students' preference and perception on teacher's written feedback on their writing tasks. The results of the analysis are presented through the count of frequency and percentage. 


\section{FINDINGS}

\section{A. Students' Perception on Teachers' Written Feedback}

This study aims to answer a question on 'What are the students' perceptions on teacher's written feedback?' Based on the results obtained, students' perceptions can be divided into two, positive feelings and negative feelings upon receiving teacher's written feedback.

\section{(i) Positive feelings upon receiving written feedback}

Students' feelings towards teachers' written feedback are highly essential to take note as perception of a person is greatly affected by one's emotions. Based on the questionnaire, students have reacted positively towards several positive feelings. The highest percentage of students $(85.2 \%)$ think that they feel improved with teachers' written feedback. Next, $84.1 \%$ of students feel cared for when they receive written feedback from teacher. A total of $82 \%$ of students feel assessed, while $74.4 \%$ of students feel satisfied when they receive teacher's written feedback.

Table I: Positive feelings on written feedback

\begin{tabular}{lll}
\hline Items & $\begin{array}{l}\text { Frequency } \\
\text { (Percentage) }\end{array}$ & \\
\hline $\begin{array}{l}\text { When I get teacher's } \\
\text { written feedback, I } \\
\text { feel: }\end{array}$ & $\begin{array}{l}\text { Strongly } \\
\text { disagree/ } \\
\text { Disagree }\end{array}$ & $\begin{array}{l}\text { Strongly } \\
\text { agree/ Agree }\end{array}$ \\
\hline Improved & $14(14.9 \%)$ & $80(85.2 \%)$ \\
\hline Cared for & $15(15.9 \%)$ & $79(84.1 \%)$ \\
\hline Assessed & $35(37.3 \%)$ & $77(82 \%)$ \\
\hline Satisfied & $24(25.5 \%)$ & $70(74.4 \%)$ \\
\hline
\end{tabular}

Besides, $83 \%$ of students are willing to wait for the written feedback patiently when it takes long to receive written feedback, whereas $17 \%$ of students disagree or strongly disagree to this statement.

Table II: Positive feeling upon delay in written feedback

\begin{tabular}{lll}
\hline Items & $\begin{array}{l}\text { Frequency } \\
\text { (Percentage) }\end{array}$ & \\
\hline $\begin{array}{l}\text { When I have to wait } \\
\text { long for teacher's }\end{array}$ & $\begin{array}{l}\text { Strongly } \\
\text { disagree/ }\end{array}$ & $\begin{array}{l}\text { Strongly } \\
\text { agree/ Agree }\end{array}$ \\
\hline Written feedback, I: & Disagree & \\
\hline
\end{tabular}

\section{(ii) Negative feelings on written feedback}

As part of students' perception towards teacher's written feedback, students have given negative reaction towards several negatively feelings when the receive teacher's written feedback. A high percentage of students have strongly disagreed or disagreed to the following statements. Firstly, $71.3 \%$ of students have strongly disagreed or disagreed to feeling humiliated when they get written feedback from teachers. Next, $68.1 \%$ of students disagreed or strongly disagreed to feeling disappointed and $67 \%$ of students don't feel frustrated and demotivated with teacher's written feedback. Whereas $58.5 \%$ students strongly disagree or disagree to being unsatisfied when they receive teacher's written feedback.
Table III: Negative feelings on written feedback

\begin{tabular}{lll}
\hline Items & $\begin{array}{l}\text { Frequency } \\
\text { (Percentage) }\end{array}$ & \\
\hline $\begin{array}{l}\text { When I get teacher's } \\
\text { written feedback, } \\
\text { feel: }\end{array}$ & $\begin{array}{l}\text { Strongly } \\
\text { disagree/ } \\
\text { Disagree }\end{array}$ & $\begin{array}{l}\text { Strongly } \\
\text { agree/ Agree }\end{array}$ \\
\hline Humiliated & $67(71.3 \%)$ & $27(28.7 \%)$ \\
\hline Disappointed & $64(68.1 \%)$ & $30(31.9 \%)$ \\
\hline Frustrated & $63(67 \%)$ & $31(32.9 \%)$ \\
\hline Demotivated & $63(67 \%)$ & $31(32.9 \%)$ \\
\hline Unsatisfied & $55(58.5 \%)$ & $39(41.5 \%)$ \\
\hline
\end{tabular}

Students have also showed their perception on how they feel whenever they had to wait long to receive written feedback from teachers. Based on the data, $45.7 \%$ of students feel demotivated, $39.3 \%$ of students feel frustrated and $45.7 \%$ of students feel impatient when they have to wait long for teacher's written feedback. A crucial point to take note is although only $30.8 \%$ of students agree or strongly agree to complain when it takes long to receive written feedback, $56.3 \%$ of students have the tendency of forgetting their essay.

Table IV: Negative feeling upon delay in written feedback

\begin{tabular}{lll}
\hline Items & $\begin{array}{l}\text { Frequency } \\
\text { (Percentage) }\end{array}$ & \\
\hline $\begin{array}{l}\text { When I have to wait } \\
\text { long for teacher's } \\
\text { written feedback, I: }\end{array}$ & $\begin{array}{l}\text { Strongly } \\
\text { disagree/ }\end{array}$ & $\begin{array}{l}\text { Strongly } \\
\text { agree/ Agree }\end{array}$ \\
\hline Disagree & \\
\hline Gemplain & $65(69.2 \%)$ & $29(30.8 \%)$ \\
\hline Get demotivated & $57(60.7 \%)$ & $37(39.3 \%)$ \\
\hline Get impatient & $51(54.2 \%)$ & $43(45.7 \%)$ \\
\hline Forget about my essay & $51(54.2 \%)$ & $43(45.7 \%)$ \\
\hline
\end{tabular}

\section{B. Area of written feedback preferred by students}

This study also aims to answer a question on 'what are preferences of students on teacher's written feedback?' Based on the outcome, students prefer receiving feedback on suggestions the most as it obtained the highest percentage (91.5\%). Next, students prefer obtaining feedback on vocabulary as it received the second highest percentage $(90.5 \%)$. Also $89.3 \%$ of students prefer receiving written feedback on content, $88.3 \%$ of students prefer grammar, $83 \%$ of students prefer organization, $80.9 \%$ of students prefer spelling, $78.8 \%$ of students prefer punctuation and out of all aspects, capitalization which received $73.4 \%$ is perceived to be least preferred by students. It is notable that even the least preferred language area has received quite a high percentage of preference.

Table V: Students' preferences on written feedback

\begin{tabular}{lll}
\hline Items & $\begin{array}{l}\text { Frequency } \\
\text { (Percentage) }\end{array}$ & \\
\hline $\begin{array}{l}\text { I prefer receiving } \\
\text { written feedback on: }\end{array}$ & $\begin{array}{l}\text { Strongly } \\
\text { disagree/ } \\
\text { Disagree }\end{array}$ & $\begin{array}{l}\text { Strongly } \\
\text { agree/ Agree }\end{array}$ \\
\hline Suggestions & $8(8.5 \%)$ & $86(91.5 \%)$ \\
\hline Vocabulary & $9(9.5 \%)$ & $85(90.5 \%)$ \\
\hline
\end{tabular}




\begin{tabular}{lll}
\hline Content & $10(10.7 \%)$ & $84(89.3 \%)$ \\
\hline Grammar & $11(11.7 \%)$ & $83(88.3 \%)$ \\
\hline Organization & $16(17 \%)$ & $78(83 \%)$ \\
\hline Spelling & $18(19.1 \%)$ & $76(80.9 \%)$ \\
\hline Punctuation & $20(21.2 \%)$ & $74(78.8 \%)$ \\
\hline Capitalization & $25(26.6 \%)$ & $69(73.4 \%)$ \\
\hline
\end{tabular}

\section{DISCUSSION}

The ultimate purpose of the study is to determine students' perception and preference on teachers' written feedback towards their writing tasks, particularly on essay compositions which is the biggest means by which writing skills are tested in education field. This study also fills the literature gap by revealing the Chinese Independent High School students' perception on teachers' written feedback in writing skills. Their perception is gained to be informed about the importance of teachers' written feedback on students through the percentage of response received on positive and negative feedback.

The outcome of this study implies several essential information about teachers' written feedback practice. The outcome of the study reveals that students from Chinese Independent High School view written feedback as useful to improve their writing skill as $85.2 \%$ of students feel improved with teachers' written feedback. This is in support of a study conducted by Saidon et al. [41], who revealed that the participants from three Malaysian secondary school perceived that written feedback was helpful to improve their writing skill. Therefore, we can conclude that the perceptions of Chinese Independent High School students are similar to the perceptions of national type secondary school students. This is also in agreement with Fithriani [21]'s study that students have improved in their writing after receiving written feedback. Besides, a high percentage of students also showed positive feelings towards written feedback as a huge number of students agreed to positive emotions such as cared for, satisfied, assessed and more and disagreed to negative feelings such as frustrated, demotivated, humiliated, unsatisfied and more. Majority also agreed to even wait patiently even if it takes long to receive the written feedback.

According to the study, five of the most preferred area of written feedback are suggestions, vocabulary, content, grammar and organization. Although other areas such as spelling, punctuation and capitalization received lesser preference, they still obtained at least a high percentage of $73.4 \%$. Thus, we can conclude that students give equal importance to both global (i.e content, organization, etc.) and local feedbacks (i.e grammar, vocabulary, etc.). This is in line with a study conducted by Seker \& Dincer [42] which claimed that students preferred feedback on both form(global) and content (local). However, this is in contrast with several studies which investigated students' preference on written feedback. They revealed that students either prioritize local aspects or global aspects compared to the other [3][51][21][2][6]. Hence, based on the preferences of students in this study, teachers are recommended to give written feedbacks which focuses on global and local feedbacks. Besides, there are many differences among the preferences of students from Chinese Independent School and national type secondary school. In this study, students' preferences focused on suggestion, vocabulary, content and followed by grammar. This is in contrast to a study conducted by Malini et al. [36], whereby Malaysian secondary school students gave more preference on grammar compared to other aspects of language such as vocabulary and content. Moreover, in this study, punctuation was viewed as one of the least preferred written feedback but in Malaysian secondary school context, it is considered as second most preferred feedback to improve their writing [41].

The outcome of the study also reveals that although students claim to wait for teachers' written feedbacks patiently and numerous students don't complain about it, there is a prominent tendency for them to forget about their essay when it takes long to be received. This implies that late submission of teachers' feedback has an impact on students' written performance. This is supported by Seker \& Dincer [42] who asserts that teachers must provide feedback in a timely manner. Therefore, teachers are highly recommended to provide their written feedback as soon as possible to avoid loss of interest in order to produce the best out of a student's writing skill. The study also depicts that students are interested vocabulary as it received the second highest preference. The lack of vocabulary may be due to the claim that Chinese Independent School students have lesser exposure to the English language as they frequently use their mother tongue compared to English [13]. Thus, they want to learn appropriate words or new words which can express their ideas in the essay. Therefore, teachers are recommended to pay more attention on the list of suitable vocabulary which can enhance their writing before assigning the task to them.

\section{CONCLUSION}

A survey carried out on a group of students from a Chinese Independent High School to identify their perceptions and preferences of teachers' written feedback in essay composition. The study concludes that students perceive teacher's written feedback positively as it is viewed to bring improvement in their writing skill. They give high importance to teachers' written feedback and the feedbacks are also perceived to play a huge role in improving students' essay writing skill. Besides, students' overall preference on teachers' written feedback also suggests that they prefer to receive written feedback on both global and local issues.

Undeniably, it is highly crucial for teachers to determine the type of feedback students prefer in improving their writing skills. This is because if they receive desired written feedback, the more they would show positive response towards the feedback. Consequently, students will be motivated to amend their mistakes and thus enhance their writing skill. Furthermore, the preferred written feedbacks can be effective in improving their writing skill because written feedbacks provided by the teachers scaffold the students in producing a better piece of writing. As mentioned by Vygotsky [48], learner interacts or cooperates with a more competent person who is the teacher to provide support and scaffold the learners through modelling of their thinking processes through the written feedbacks. Moreover, the results of the current study are also likely to provide a step to 
shape the feedback process in Chinese Independent High school context while bidding to suggest a point to the area of second language writing instruction.

\section{REFERENCES}

[1] Alamis, M. M. P. "Evaluating Students' Reactions and Responses to Teachers' Written Feedback”. Philippine ESL Journal, 2010, 5: 40-57.

[2] Ali, H. \& Francisco, P. D. "Form and Content Feedbacks in Foreign Language Writing: The Case of Omani Learners of English". Language in India. 2014, 14:11 3-16.

[3] Amelia, A. T, Affidah, M., Lilly, M. \& Saira, J. "Students' Perception and Preferences of Written Feedback in Academic Writing". Mediterranean Journal of Social Sciences MCSER Publishing, Rome-Italy. 2013, 4(11): 72-80.

[4] Amrhein, H. R., \& Nassaji, H. "Written Corrective Feedback: What do Students and Teachers Think is Right and Why?" Canadian Journal of Applied Linguistics, 2010, 13(2), 95-127.

[5] Ashwell, T. "Patterns of Teacher Response to Student Writing in a Multiple-Draft Composition Classroom: Is Content Feedback Followed by Form Feedback the Best Method?" Journal of Second Language Writing, 2000, 9(3): 227-257.

[6] Baghzou, S. "The Effects of Content Feedback on Students' Writing". Ankara Universitesi Dil ve Tarih-Cografya Fakultesi Dergisi, 2011, 51: $169-180$

[7] Bailey, R., \& Garner, M. "The feedback in higher education assessment worth the paper it is written on? Teachers' reflections on their practices". Teaching in Higher Education, 2010, 15(2): 187-198.

[8] Barnard, R., de Luca, R., \& Li, J. "First year undergraduate students' perceptions of lecturer and peer feedback: A New Zealand action research project". Studies in Higher Education, 2015, 40(5): 933-944.

[9] Bitchener, J., \& Knoch, U. "The contribution of written corrective feedback to language development: A ten-month investigation". Applied Linguistics, 2009, 31(2): 193-214.

[10] Bryman, A. Social Research Methods. New York: Oxford University Press, 2001.

[11] Carless, D. "Differing perceptions in the feedback process". Studies in Higher Education, 2006, 31(2): 219-233.

[12] Chandler, J. "The efficacy of various kinds of error feedback for improvement in the accuracy and fluency of L2 student writing". Journal of Second Language Writing, 2003, 12: 267-269.

[13] Chieng, S. L. "The effects of direct and indirect written corrective feedback on the use of present tenses among ESL learners". Master's thesis, Universiti Malaya, Malaysia, 2014.

[14] Cohen, A. D., \& Cavalcanti, M. C. "Feedback on compositions: Teacher and student verbal reports". In Kroll, B. (Ed.), Second language writing: Research insights for the classroom, 1990, 155-177.

[15] Cronbach, L. J. "Coefficient alpha and the internal structure of tests". Psychometrika, 1951, 16: 297-334.

[16] Ellis, R. "A typology of written corrective feedback types". ELT Journal, 2009, 63(2): 97-107.

[17] Fathman, A. \& Whalley, E. "Teacher response to student writing: Focus on form versus content". In B. Kroll (Ed.), Second language writing: Research insights for the classroom, 1990, 178-190.

[18] Ferris, D. R. 1997. "The Influence of Teacher Commentary on Student Revision". TESOL Quarterly, 1997, 31(2): 315- 339.

[19] Ferris, D. "The case of grammar correction in L2 writing classes: A response to Truscott (1996)". Journal of Second Language Writing, 1999, 8(1): 1-11.

[20] Ferris, D. R. "Does error feedback help student writers? New evidence on the short- and long-term effects of written error correction". In K. Hyland \& F. Hyland (Eds.), Feedback in second language writing, 2006, 81-104

[21] Fithriani, R. "Indonesian Students' Perceptions of Written Feedback in Second Language Writing". 2017. Language, Literacy, and Sociocultural Studies ETDs. https://digitalrepository.unm.edu/educ_llss_etds/87

[22] Graham, S. "Facilitating writing development". In D. Wyse, R. Andrews, \& J. Hoffman (Eds.), The Routledge international handbook of English language, and literacy Teaching, 2010, 125-136.

[23] Hamp-Lyons, L. "Fourth generation writing assessment". In T. Silva, \& P. K. Matsuda (Eds.), On second language writing, 2011, 117-128. Mahwah, NJ: Lawrence Erlbaum.

[24] Hattie, J. "Feedback in schools". In R. M. Sutton, M. J. Hornsey, \& K. M. Douglas (Eds.), Feedback: The communication of praise, criticism and advice, 2012, 265-277.
[25] Higgins, R., Hartley, P., \& Skelton, A. "Getting the message across: The problem of communicating assessment feedback". Teaching in Higher Education, 2001, 6(2): 269-274.

[26] Hounsell, D. "Student feedback, learning and development". In M. Slowey \& D. Watson (Eds.), Higher education and the life course, 2003, Maidenhead: Open University Press.

[27] Hyland, K., \& Hyland, F. "Contexts and issues in feedback on L2 writing: An introduction". In K. Hyland \& F. Hyland (Eds.), Feedback in ESL writing: Contexts and issues, 2006a, 1-19, Cambridge: Cambridge University Press.

[28] Hyland, K., \& Hyland, F. "Feedback on second language students' writing". Language Teaching, 2006b, 39: 83-101.

[29] Jahin, J. H. "The effect of peer reviewing on writing apprehension and essay writing ability of prospective EFL teachers". Australian Journal of Teacher Education, 2012, 37(11): 60-84.

[30] Kamimura, T. "Effects of peer feedback on EFL student writers at different levels of English proficiency: A Japanese context". TESL Canada Journal, 2006, 23(2): 12-39.

[31] Kee, L. L. \& Abu, B R. "Idea Sharing: Process-Based Approach to Writing in Malaysian English Education". PASAA, 2019, 58: 317-339.

[32] Kurt, G., \& Atay, D. "The effects of peer feedback on the writing anxiety of prospective Turkish teachers of EFL". Journal of Theory and Practice in Education, 2007, 3(1): 12-23.

[33] Lalande, J. F. II "Reducing composition errors: An experiment". The Modern Language Journal, 1982, 66.2, 140-149.

[34] Lee, I. "Error correction in the L2 classroom: What do students think?" TESL Canada Journal, 2005, 22: 1-16.

[35] Lee, I. "Student reactions to teacher feedback in two Hong Kong secondary classrooms". Journal of Second Language Writing, 2008a, 17(3): 144-164

[36] Malini, G., Debbita, A.L.T., \& Jonathan, P. "Impact of Written Corrective Feedback on Malaysian ESL Secondary Students' Writing Performance". 3L: The Southeast Asian Journal of English Language Studies, 2020, 26(3): 139 - 153.

[37] Ministry of Education of Malaysia. 2003. Curriculum Specifications English Language.

[38] Nicol, D. J., \& Macfarlane-Dick, D. "Formative assessment and self-regulated learning: A model and seven principles of good feedback practice". Studies in Higher Education, 2006, 31(2): 199- 218.

[39] Nooreiny, M. \& Mazlin, M. "Writing strategies used by ESL upper secondary school students". International Education Studies, 2013, 6(4): 47-55

[40] Ramsden, P. Learning to teach in higher education (2nd ed.). London, UK: Routledge Falmer, 2003.

[41] Saidon, M. A., Said, N. E. M., Soh, T. M. T., \& Husnin, H. "ESL Students' Perception of Teacher's Written Feedback Practice in Malaysian Classrooms". Creative Education, 2018, 9: 2300-2310.

[42] Seker. M. \& Dincer. A. "An Insight to Students' Perceptions on Teacher Feedback in Second Language Writing Classes". English Language Teaching, 2014, 7(2): 73-83.

[43] Servilio, K. L. "You Get to Choose! Motivating Students to Read through Differentiated Instruction”. TEACHING Exceptional Children Plus, 2009, 5: 2-11.

[44] Struyven, K., Dochy, F., \& Janssens, S. (n.d.) Students' perceptions about learning in higher education: a review (Unpublished manuscript).

[45] Talal M. Amara. "Learners' perceptions of teacher written feedback commentary In an ESL writing classroom". International Journal of English Language Teaching, 2015, 3(2): 38-53, Published by European Centre for Research Training and Development UK.

[46] Truscott, J. "The case against grammar correction in L2 writing classes". Language Learning, 1996, 46(2): 327-369.

[47] Truscott, J. "The effect of error correction on learners' ability to write accurately". Journal of Second Language Writing, 2007, 16(4): 255-272.

[48] Vygotsky, L. S. Mind in society: The development of higher psychological processes. Cambridge, MA: Harvard University Press, 1978.

[49] Wong. V. "The Language Medium Policies: A Study on the Development of Independent Chinese Secondary Schools (ICSS) in Malaysia". KATHA, 2017, 13: 32-53.

[50] Williams, J. G. "Providing feedback on ESL students' written assignments". The Internet TESL Journal, 2003, 9(10).

[51] Zhan. L. "Written Teacher Feedback: Student Perceptions, Teacher Perceptions, and Actual Teacher Performance, English Language Teaching". Canadian Center of Science and Education, 2016, 9(8): 73-84. 
Thiviyaa Maniam is a student who is pursuing her Masters of Education in TESL in National University of Malaysia, 43600 Bangi, Selangor, Malaysia. She graduated from Management \& Science University in 2017 with a Bachelor"s Degree in TESL. She is currently teaching English language in Pin Hwa High School, Klang, Selangor, Malaysia since 2017. She has participated in International Invention \& Innovative Competition (InIIC Series 2/2019) under Higher Institution Students (Social Science) category.

Parilah Mohd Shah is an Associate Professor at Faculty of Education in National University of Malaysia, 43600 Bangi, Selangor, Malaysia. She obtained her M.A. and Ph.D. from University of Connecticut, USA. Her research interest are second language acquisition, teaching methodology, bilingual-bicultural education as well as learning challenges and need among second language learners. She has presented papers at national and international levels. Besides that, she also has published several papers in areas related to second language acquisition and reading strategies. 